\title{
GREEN TEA MITIGATES STREPTOZOTOCIN-INDUCED DIABETIC MICE THROUGH ANTI-FIBROTIC ACTIVITY AND MODULATION OF PROIN- FLAMMATORY CYTOKINES
}

\author{
Hend M. Salah ${ }^{1}$, Eman A. Moussa ${ }^{1}$, Samaa M El. Bakr ${ }^{1}$, Mustafa S. Atta ${ }^{2 *}$, \\ Foad A. Farrag ${ }^{3}$, Ahmed S. Hafez
}

${ }^{1}$ Department of Zoology, Faculty of Science, Kafrelsheikh University, 33516, Egypt, ${ }^{2}$ Department of Physiology, Faculty of Veterinary Medicine, Kafrelsheikh University, ${ }^{3}$ Department of Anatomy and Embryology, Faculty of Veterinary Medicine, Kafrelsheikh University, ${ }^{4}$ Department of Pharmacology, Faculty of Veterinary Medicine, Aswan University, Egypt

*Corresponding author, E-mail: mostafa.ataa@vet.kfs.edu.eg

\begin{abstract}
This research was planned to assess the protective effect of green tea extract (GTE) in STZ-induced diabetes in mice. Seventy-five female albino mice were used. Mice randomly allocated into five groups of 15 mice in each as follows: group 1 (control), group 2 (STZ, diabetic), group 3 (green tea + STZ), group 4 (protective group with green tea), and group 5 (green tea only). Oral administration of the green tea extract for three weeks to diabetic mice resulted in significant regaining in body weight, decreased blood glucose, cholesterol, triglyceride, free fatty acid and low-density lipoprotein cholesterol (LDL-C) levels and lowered malondialdehyde (MDA) contents and increased total protein and high-density lipoprotein cholesterol (HDL-C) as compared to untreated diabetic group. Histopathological changes were compatible with these biochemical findings. Diabetic mice pre- or co-treated with green tea also exhibited a significant downregulation in TGF 1 and TNF $\alpha$ genes expression. Green tea extracts had protective and antidiabetic effect in controlling blood glucose level in addition to improving lipid metabolism and body weight in diabetic mice.
\end{abstract}

Key words: diabetes; green tea; liver; TNFa; TGF-B1; mice

\section{Introduction}

Diabetes mellitus (DM) is one of the major intimidations to health in the world. It was expected to be more prevalent in 2025 (1). Hyperglycemia is associated with vascular complications and kidney diseases (2). There are several other factors that play a great role in diabetes for instance, obesity and oxidative stress which lead to more ferocious complications (3), with decreased humoral immunity (4).
DM type 1 is a consequence of the annihilation of $\beta$-cells of the pancreas (5). Deficiency of insulin primes to hyperglycemia. STZ is a structural analog of glucose (Glu) and N- acetyl glucosamine is reserved up by $\beta$-cells via the GLUT 2 transporter subsequently lead to $\beta$-cell loss via DNA destruction $(6,7)$. Moreover, cells that express GLUT 2 transporter like liver and kidney cells are also vulnerable to STZ. This clarifies kidney and liver complications $(8,9)$. 
Oxidative anxiety is an inequity among the reactive oxygen species (ROS) and antioxidant protection of the body, which play a great role in diabetic complications (10). Since many studies stated that oxidative anxiety, facilitated by diabetes-induced production of ROS, lead to progress of diabetes, it noticed that improving oxidative anxiety via antioxidants might be a successful approach for demoting diabetic complications $(11,12)$.

Green tea (Camellia sinensis) is prevalent nutraceutical antioxidant especially in Asian countries (13). Green tea has an important role in decreasing blood pressure, low-density lipoprotein cholesterol, and oxidative stress (14). Many studies proved the valuable effects of green tea on diabetic complications $(15,16)$ as well as it has antihyperglycemic effect in STZ diabetic animals (17). Moreover, green tea shows antioxidants and free radicals scavenger properties (18).

This study was done to evaluate the protecting pathway by which green tea alleviate streptozotocin-induced diabetes in mice.

\section{Material and methods}

\section{Chemicals}

We utilized a pharmaceutical-grade of STZ from Sigma (St. Louis, MO, USA). The STZ solution prepared by dissolving STZ in citrate buffer (0.01 M, pH 4.5) (19, 20). Chemicals consumed were of analytical grade. Total cholesterol, high-density lipoprotein (HDL)-cholesterol and triglyceride (TG) standard kits were purchased from Erba Diagnostics Mannheim Gambh, Germany.

\section{Green tea extract}

The green tea tablets, each tablet contain green tea extract $200 \mathrm{mg}$ manufactured by $\mathrm{El}$ Obour City pharmaceutical industries. Following grinding, the obtained green tea powder dissolved in distilled water. This solution was provided to mice orally by using a stomach tube.(21)

\section{Experimental animals}

Seventy-five female albino mice, $(9-11$ weeks old, weighing about 25-30 gm was used.
They obtained from Medical Technology Center, University of Alexandria, Egypt. Animals were managed according to the rules and regulations of our university committee. Female albino mice were housed in stainless steel pens of ambient temperature $23 \pm 2^{\circ} \mathrm{C}$ and light $(12 \mathrm{~h}$ light/12 h dark) and free access to food and water. The mice were fed a standard diet according to $(22)$.

\section{Initiation of experimental diabetes}

After 2 weeks of accommodation, the mice were exposed to a $12 \mathrm{~h}$ fast. The mice were I/P injected with a single dose of $200 \mathrm{mg} / \mathrm{kg} \mathrm{STZ}$ $(7,19)$. STZ was freshly dissolved in $0,1 \mathrm{M}$ cold sodium citrate buffer, $\mathrm{pH} 4.5(19,20)$.after $2 \mathrm{~h}$ from injecting we put $5 \%$ glucose and food to injected mice to avoid death(20) .we replace $5 \%$ glucose with water after $2 \mathrm{~h}$. The urine glucose level was checked three days after STZ injection to check the progress of diabetes. The diabetic mice were steadied for 5 days and then the experiment beginning. Mice which showed glucose levels $>250 \mathrm{mg} / \mathrm{dL}$ was considered diabetic.

\section{Experimental design}

After acclimatization, mice were alienated randomly into five groups of 15 mice each: Group 1: healthy control mice received distilled water Group 2 (diabetic group): will be used as control diabetic mice. The mice were injected I/P with one dose of $200 \mathrm{mg} / \mathrm{kg} \mathrm{STZ}(7,19)$. In group 3 (treated group with green tea) diabetic mice were administrated green tea at a dose of $200 \mathrm{mg} / \mathrm{kg}$ bw orally by stomach tube daily for 21 days. In group4 (protective group with green tea) mice were given green tea at dose of 200 $\mathrm{mg} / \mathrm{kg}$ by stomach gavage for 21 days and then diabetes was induced with a single dose of 200 $\mathrm{mg} / \mathrm{kg}$ streptozotocin with continuous treatment with green tea at dose of $200 \mathrm{mg} / \mathrm{kg}$ orally for 21days. In group 5 (control green tea group) non-diabetic mice received green tea (200 $\mathrm{mg} / \mathrm{Kg}$ /day)dissolved in distilled water orally by stomach tube for 21 days according to (23). 


\section{Sampling}

Mice were sacrificed by cervical decapitation. Body weights of all the animals were recorded prior to the treatment and sacrifice. Weight change $\%=$ Initial weight - Final weight $\times 100 /$ Initial weight

Blood samples were collected in either EDTA coated tubes for the hematological investigation or plain tubes for serum separation (24) for biochemical assays. Kidneys, liver, spleen, and pancreases after decapitation were quickly removed and washed by cold saline to remove extraneous materials. Each organ was divided into 3 specimens. The first was snap frozen with liquid $\mathrm{N} 2$ and kept at $-80^{\circ} \mathrm{C}$ until use for RNA extraction. The second was fixed in $10 \%$ neutral buffered formalin for the histological examination. The third was used for transmission electron microscopy (TEM) handled using standard techniques.

\section{Blood analysis}

The serum samples for measurement of blood glucose level was determined based on glucose oxidase method (25), insulin concentrations were determined according to (26) using an insulin-ELISA kit (Morinaga Seikagaku, Tokyo, Japan). Malondialdehyde (MDA) was quantified by the method of Ohakawa et al. (27), HbAlc was appraised using DCA 2000 analyzer (Bayer, Elkhart, IN)(28, 29). Total protein concentration in serum was assayed colorimetrically using commercial kit (Diamond, Egypt) and according to Lowry et al. (1951). Serum levels of total cholesterol, triglycerides, and high-density lipoproteins cholesterol (HDL-C) were estimated by quantitative colorimetric assay (Stanbio Laboratory, Inc., Texas, USA) according to (30) and low-density lipoprotein cholesterol (LDL-C) concentration assessed according to the formula of Friedewald et al; (31). LH, FSH, and estrogen were assessed using IMMULITE chemiluminescent assay kits (DPC, Glyn Rhonwy, Llanberis, Gwynedd, UK)(32). The Horiba ABX 80 Diagnostics (ABX pentra Montpellier, France) was used for hematological examination (33).
Histopathological and transmission electron microscope examination

The histopathology was carried out according to (34) using hematoxylin and eosin staining technique. Preparation od samples for transmission electron microscope (TEM) using collagen-coated nickel grids was applied as previously described (35).

\section{Molecular investigation}

Total RNA was extracted from tissue samples using RNA extraction kit (easy-REDTM, iNtRON Biotechnology, \#17063, South Korea). cDNA synthesis was performed using reverse transcription kits (Thermo Scientific, Fermentas, \#EP0451) which include the following: Revert Aid H Minus Reverse Transcriptase enzyme, Oligo dT,5X Reaction Buffer, RiboLock RNase Inhibitor, and dNTP Mix. Concentration of RNA and cDNA quantify using a Nanodrop (Q5000 Uv-Vis spectrophotometer, USA).

Real-time PCR with SYBR Green (2X Maxima SYBR Green/ROX qPCR Master Mix) used to determine the expression of the target genes in the liver, with GAPDH as a housekeeping gene, according to the manufacturer protocol (Thermo Scientific, USA, \# K0221). The primers used in the amplification are shown in Table 1. The web-based tool, Primer 3 (http://www-genome.wi.mit.edu/cgibin/primer/primer3_www.cgi) used to design these primers. To confirm primer sequence is unique for the template sequence; we check similarity to other known sequences with BLAST. Calculation of fold changes in gene expression was done using $2^{-\Delta \Delta \mathrm{Ct}}$ method.

\section{Statistical analysis}

Data was analyzed using GraphPad Prism 5 (GraphPad Software, San Diego, CA, USA). Results subjected to Tukey's multiple comparisons post-hoc test. Values are statistically significant when $\mathrm{p}<0.05$.

\section{Results}

\section{Growth weight and Biochemical analysis}

Diabetic mice had a significant drop in body weight in relation to other groups.as shown in 
figure 1 .The diabetic mice showed a significantly increased level of serum glucose, triglycerides, cholesterol, LDL-C, VLDL-C relative to the control group and other treated groups and green tea protective groups. Serum insulin, total protein and HDL-C statistically decreased in diabetic mice as compared to the control group, treated and green tea protective groups (Table 2). Serum HbA1C pointedly increased in diabetic mice relative to the control group (Table 2). Diabetic mice showed a noteworthy increase in MDA compared to their equivalent levels in control animals. However, treated groups with green tea showed a significant diminution in the levels of MDA in relation to diabetic mice. Protective groups treated with green tea exhibited a significant reduced MDA levels as compared to diabetic mice (Table 2). LH, FSH and estrogen levels did not show any significant difference among all groups (Table 3).

\section{Hematological analysis}

RBC and WBC count, PCV, neutrophil \% and platelets levels in diabetic mice decreased significantly, while $\mathrm{MCV}, \mathrm{MCH}$, and $\mathrm{MCHC}$ increased significantly in diabetic mice compared to the control mice. Green tea extract significantly normalized RBC and WBC count, $\mathrm{PCV}$, neutrophil \% and platelets in diabetic mice as well as MCV, MCH, and MCHC of diabetic mice to the control level (Table 4).

\section{Histopathological studies}

All results of histopathology were displayed in figure 2. Histopathological observation revealed that liver of the control animal showing normal hepatocytes arranged in cords around the central vein (arrowhead) whereas that of STZ-treated animal showing single cell necrosis (arrowhead) associated with active apoptosis (arrow). Green tea treated diabetic animal showing slight hepatic vacuolation (arrowhead) adding that liver of green tea group showing normal hepatocytes around the central vein (arrow) as well as liver of protective group pretreated with green tea showing normal hepatocytes arranged around the central vein (arrow). Kidney of control animal showing normal renal glomeruli (arrowhead) and tubules (arrow) while kidney (cortex) of STZ-treated animal showing marked glomerular congestion (arrowhead) and degeneration within renal tubules (arrow) while that of green tea treated diabetic animal showing normal renal glomeruli (arrowhead) and patent normal tubules (arrow). Green tea group showing normal renal glomeruli (arrowhead) and tubules (arrow). Kidney of protective group with green tea-treated animal showing renal glomeruli (arrowhead) and tubules (arrow) within the normal limits. Pancreas of control animal showing normal glandular acini (arrow) and $\beta$ islets (arrowhead) while that of STZ-treated animal showing degeneration of both glandular acini (arrow) and $\beta$ islets (arrowhead). Green tea treated diabetic animal showing normal glandular acini (arrow) and slight vacuolation of $\beta$-cells (arrowhead) as well as pancreas of green tea-treated animal showing normal glandular acini and $\beta$ islets (arrowhead). Diabetic animal pre-and post-treated with green tea-treated animal showing normal glandular acini (arrow) and $\beta$ cells (arrowhead).

\section{Electron microscope studies}

All results of transmission electron microscope were displayed in figure 3 . Liver of control group showing normal hepatocytes $\mathrm{M}$ indicates mitochondria and $\mathrm{N}$ indicates nucleus. While that liver of diabetic group showing multilocular cytoplasmic fat vacuoles, decreased mitochondrial number and shrinkage of nuclear membrane. As well as, liver of green tea treated diabetic animals showing presence of small fat vacuoles, glycogen granules and multiple autophagic vacuoles. besides green tea group showing three adjacent hepatocytes separated with thin connective tissue layer and mostly normal. $M$ indicates mitochondria, bar $=500$ $\mu \mathrm{m}$., liver of protective group treated with green tea group showing moderate degree of hepatic steatosis, F indicates fat vacuoles. Pancreas (endocrine portion) of control group showing presence of large number of $\mathrm{B}$ secretary granules within the B cells (arrowhead), BC indicates blood capillary, pancreas of diabetic group showing exocrine pancreatic cell with noticeable decrease the number of secretory granules 
and mostly immature (arrowhead) with corrugated nuclear membranes (arrow), while that Green tea treated diabetic group showing exocrine pancreatic cell revealing normal nucleus (N) and with normal network of rough endoplasmic reticulum (RER), pancreas of green tea group showing two adjacent exocrine cells with normal nuclei and surrounded with network of rough endoplasmic reticulum, in addition, pancreas (exocrine cell) of protective group pretreated with green tea showing normal nucleus surrounded with network of rough endoplasmic reticulum and revealing large number of mature secretory vesicles (arrowhead). kidney of control group showing normal lining epithelial cells of the distal renal tubules with normal mitochondria (M) with mild condensation. Adding, kidney of STZ treated group showing the lining epithelial cells of the proximal tubules with slightly condensed mitochondria and some of them showing presence of fat vacuoles (arrowhead) and with normal brush border covering (arrow). as well as, green tea treated diabetic group showing lining epithelial cells of the distal renal tubules and mostly revealing lysis of the most intracellular organelles (arrow), kidney of green tea group showing the proximal renal tubules lining epithelial cells with normal brush border and mitochondria (M), bar=500 $\mu \mathrm{m}$., while that of protective group pretreated with green tea group showing lining epithelial cells of the distal renal tubules and mostly revealing lysis of the most intracellular organelles (arrows).
Outcome of streptozotocin, green tea on the relative expression of TGF $\beta$ lgene and $T N F \alpha$ gene

The results of qPCR were presented in Figure 4. A considerable upregulation in the expression of $T G F \beta 1$ gene in liver was found following administration of Streptozotocin as compared to the control group and other treated groups. Green tea treated diabetic mice showed a noteworthy decrease $T G F \beta 1$ gene expression as compared to the diabetic group. Furthermore, pre-treatment by green tea led to a significant decrease in TGF $\beta 1$ expression. Green tea alone led to insignificant downregulation of $T G F \beta 1$ gene expression as compared to the control group. $T N F \alpha$ upregulation was found following administration of Streptozotocin as matched to normal one and other treated groups. Administration of green tea with Streptozotocin resulted in a significant decrease in $T N F \alpha$ gene expression as compared to diabetic one. Furthermore, pre-treatment by green tea led to a significant reduction of $T N F \alpha$ expression. Administration of green tea alone led to momentous decreased of TNFa gene expression in relation to control group.

Table 1: Sequences of primers used in qPCR

\begin{tabular}{|c|l|l|l|l|}
\hline Gene & \multicolumn{1}{|c|}{$\begin{array}{c}\text { Reverse primer } \\
(/ 5-----/ 3)\end{array}$} & \multicolumn{1}{|c|}{$\begin{array}{c}\text { Forward primer } \\
(/ 5-----/ 3)\end{array}$} & $\begin{array}{l}\text { Size } \\
(\mathrm{bp})\end{array}$ & $\begin{array}{c}\text { Accession } \\
\text { number }\end{array}$ \\
\hline TGF $\beta 1$ & $\begin{array}{l}\text { GACGTCAAAAGA- } \\
\text { CAGCCACTCA }\end{array}$ & $\begin{array}{l}\text { GCAACATGTGGAACTC- } \\
\text { TACCAGA }\end{array}$ & 106 & M13177 \\
\hline TNF $\alpha$ & $\begin{array}{l}\text { CTGATGA- } \\
\text { GAGGGAGGCCATT }\end{array}$ & $\begin{array}{l}\text { GCCTCTTCTCATTCCTG } \\
\text { CTTG }\end{array}$ & 115 & $\begin{array}{l}\text { NM_00127860 } \\
1\end{array}$ \\
\hline GAPDH & $\begin{array}{l}\text { CCTGCTTCACCACC } \\
\text { TTCTTGA }\end{array}$ & $\begin{array}{l}\text { TGTGTCCGTCGTG- } \\
\text { GATCTGA }\end{array}$ & 99 & M32599 \\
\hline
\end{tabular}


Table 2: Effect of green tea on serum glucose, HbA1C, insulin, MDA, total protein levels in STZ-induced diabetic female albino mice

\begin{tabular}{|l|c|c|c|c|c|}
\hline & Control & STZ & STZ+Green tea & $\begin{array}{c}\text { pretreated with } \\
\text { green tea }\end{array}$ & Green tea \\
\hline Glucose $(\mathrm{mg} / \mathrm{dl})$ & $120.5 \pm 13^{\mathrm{c}}$ & $407 \pm 49.6^{\mathrm{a}}$ & $186 \pm 27^{\mathrm{b}}$ & $115 \pm 23^{\mathrm{c}}$ & $143 \pm 4.7^{\mathrm{bc}}$ \\
\hline HbA1C $(\%)$ & $5.00 \pm 0.0^{\mathrm{c}}$ & $13.0 \pm 0.44^{\mathrm{a}}$ & $8.2 \pm 0.58^{\mathrm{b}}$ & $5.0 \pm 0.0^{\mathrm{c}}$ & $8.2 \pm 0.58^{\mathrm{b}}$ \\
\hline Insulin $\mathrm{pg} / \mathrm{ml}$ & $1024 \pm 0.0^{\mathrm{a}}$ & $299.0 \pm 0.0^{\mathrm{c}}$ & $606 \pm 21.7^{\mathrm{b}}$ & $1024 \pm 0.0^{\mathrm{a}}$ & $826 \pm 50.8^{\mathrm{b}}$ \\
\hline MDA nmol/ml & $0.557 \pm 0.0^{\mathrm{c}}$ & $1.90 \pm 0.0^{\mathrm{a}}$ & $1.0 \pm 0.06^{\mathrm{b}}$ & $0.57 \pm 0.0^{\mathrm{c}}$ & $0.8 \pm 0.01^{\mathrm{b}}$ \\
\hline $\begin{array}{l}\text { Total protein } \\
\text { (mg/dl) }\end{array}$ & $6.21 \pm 0.17^{\mathrm{a}}$ & $4.44 \pm 0.18^{\mathrm{c}}$ & $6.175 \pm 0.4^{\mathrm{a}}$ & $6.14 \pm 0.12^{\mathrm{a}}$ & $5.30 \pm 0.46^{\mathrm{b}}$ \\
\hline
\end{tabular}

Data are expressed as mean \pm SEM.Superscript of different letters in each column differ significantly $(\mathrm{P}<0.05)$ from each other

Table 3: Effect of green tea on LH, FSH and estrogen level levels in STZ-induced diabetic female albino mice

\begin{tabular}{|l|c|c|c|c|c|}
\hline & Control & STZ & STZ+Green tea & $\begin{array}{c}\text { pretreated with } \\
\text { green tea }\end{array}$ & Green tea \\
\hline Estrogen $(\mathrm{pg} / \mathrm{ml})$ & $24.2 \pm 0.3$ & $22.8 \pm 0.5$ & $23.0 \pm 0.4$ & $23.6 \pm 0.24$ & $22.8 \pm 0.37$ \\
\hline FSH $(\mathrm{pg} / \mathrm{ml})$ & $0.18 \pm 0.0$ & $0.17 \pm 0.0$ & $0.15 \pm 0.00$ & $0.18 \pm 0.0$ & $0.17 \pm 0.0$ \\
\hline $\mathrm{LH}(\mathrm{pg} / \mathrm{ml})$ & $0.36 \pm 0.0$ & $0.36 \pm 0.0$ & $0.35 \pm 0.0$ & $0.36 \pm 0.0$ & $0.36 \pm 0.0$ \\
\hline
\end{tabular}

Data are expressed as mean \pm SEM. Superscript of different letters in each column differ significantly $(\mathrm{P}<0.05)$ from each other

Table 4: Effect of green tea on Haemogram in STZ-induced diabetic female albino mice

\begin{tabular}{|c|c|c|c|c|c|}
\hline & Control & STZ & $\begin{array}{c}\text { STZ+Green } \\
\text { tea }\end{array}$ & $\begin{array}{c}\text { pretreated with } \\
\text { green tea }\end{array}$ & Green tea \\
\hline RBC $(10 \% / \mathrm{ul})$ & $8.88 \pm 0.6^{\mathrm{a}}$ & $7.45 \pm 0.13^{\mathrm{c}}$ & $8.31 \pm 0.18^{\mathrm{b}}$ & $8.6 \pm 0.04^{\mathrm{ab}}$ & $8.07 \pm 0.05^{\mathrm{b}}$ \\
\hline $\mathrm{Hb}(\mathrm{g} / \mathrm{dl})$ & $15.4 \pm 0.18^{\mathrm{a}}$ & $12.9 \pm 0.24^{\mathrm{c}}$ & $14.5 \pm 0.2 \mathrm{~b}^{\mathrm{a}}$ & $14.3 \pm 0.21^{\mathrm{b}}$ & $14.5 \pm 0.2^{\mathrm{ab}}$ \\
\hline $\mathrm{HCT} \%$ & $29.48 \pm 0.3^{\mathrm{c}}$ & $37.0 \pm 0.42^{\mathrm{a}}$ & $31.2 \pm 0.33^{\mathrm{b}}$ & $31.0 \pm 0.48^{\mathrm{b}}$ & $29.2 \pm 0.20^{\mathrm{c}}$ \\
\hline $\mathrm{MCV}(\mathrm{fl})$ & $40.7 \pm 0.28^{\mathrm{c}}$ & $46.0 \pm 0.28^{\mathrm{a}}$ & $43.0 \pm 0.35^{\mathrm{b}}$ & $43.1 \pm 0.23^{\mathrm{b}}$ & $40.7 \pm 0.35^{\mathrm{c}}$ \\
\hline $\mathrm{MCH}(\mathrm{pg})$ & $13.2 \pm 0.09^{\mathrm{c}}$ & $17.5 \pm 0.21^{\mathrm{a}}$ & $14.1 \pm 0.13^{\mathrm{c}}$ & $13.9 \pm 0.05^{\mathrm{c}}$ & $13.65 \pm 0.1^{\mathrm{c}}$ \\
\hline $\mathrm{MCHC}(\mathrm{g} / \mathrm{dl})$ & $30.3 \pm 0.23^{\mathrm{c}}$ & $41.4 \pm 0.25^{\mathrm{a}}$ & $33.4 \pm 0.34^{\mathrm{b}}$ & $32.83 \pm 0.1^{\mathrm{b}}$ & $31.1 \pm 0.13^{\mathrm{c}}$ \\
\hline WBC $\left(10^{3} / \mathrm{ul}\right)$ & $17.0 \pm 0.07^{\mathrm{a}}$ & $3.54 \pm 0.39^{\mathrm{c}}$ & $7.07 \pm 0.22^{\mathrm{b}}$ & $7.82 \pm 0.44^{\mathrm{b}}$ & $6.15 \pm 0.42^{\mathrm{c}}$ \\
\hline Lymphocyte \% & $65.0 \pm 0.16^{\mathrm{a}}$ & $11.94 \pm 4.1^{\mathrm{c}}$ & $45.65 \pm 4.1^{\mathrm{b}}$ & $44.59 \pm 3.3^{\mathrm{b}}$ & $61.21 \pm 0.6^{\mathrm{a}}$ \\
\hline Monocyte \% & $17.8 \pm 0.11^{\mathrm{a}}$ & $5.345 \pm 0.4^{\mathrm{c}}$ & $14.95 \pm 0.0^{\mathrm{b}}$ & $13.83 \pm 0.2^{\mathrm{b}}$ & $17.08 \pm 0.1^{\mathrm{a}}$ \\
\hline Granulocytes \% & $70.1 \pm 2.50^{\mathrm{a}}$ & $29.48 \pm 1.5^{\mathrm{c}}$ & $52.00 \pm 1.5^{\mathrm{b}}$ & $56.18 \pm 1.3^{\mathrm{b}}$ & $69.75 \pm 1.9^{\mathrm{a}}$ \\
\hline Platelets (103/ul) & $637.5 \pm 54^{\mathrm{a}}$ & $349.3 \pm 17^{\mathrm{c}}$ & $422 \pm 13.9^{\mathrm{bc}}$ & $543.0 \pm 13^{\mathrm{b}}$ & $486 \pm 14.6^{\mathrm{b}}$ \\
\hline
\end{tabular}

Data are expressed as mean \pm SEM. Superscript of different letters in each column differ significantly $(\mathrm{P}<0.05)$ from each other 


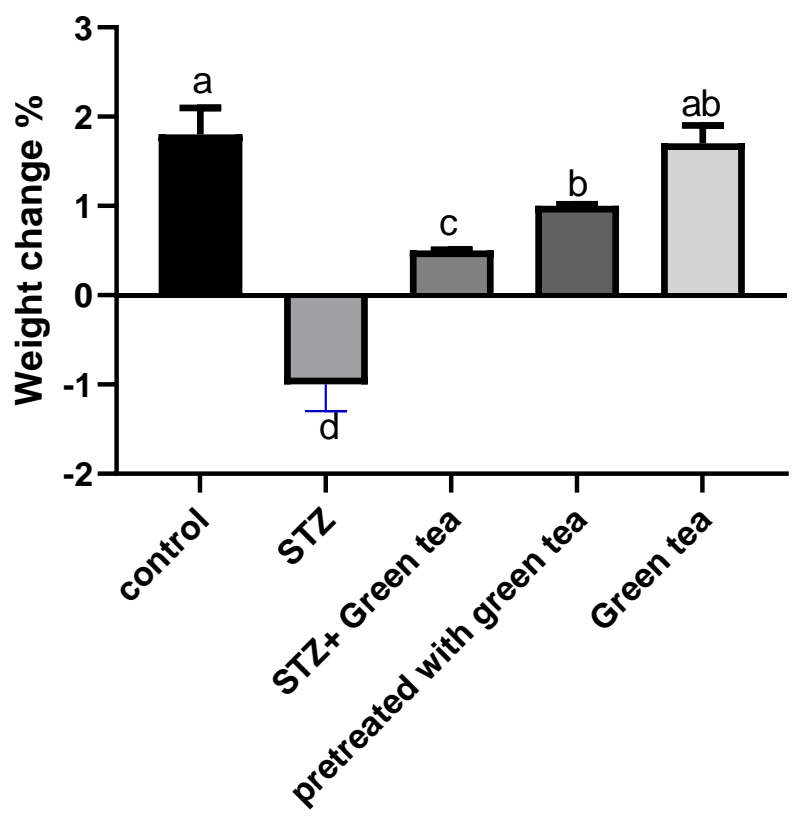

Figure 1: Effect of green tea on body weight, food intake and water intake grade in STZ-induced diabetic female albino mice. Data are expressed as mean \pm SEM. Superscript of different letters in each column differ significantly $(\mathrm{P}<0.05)$ from each other
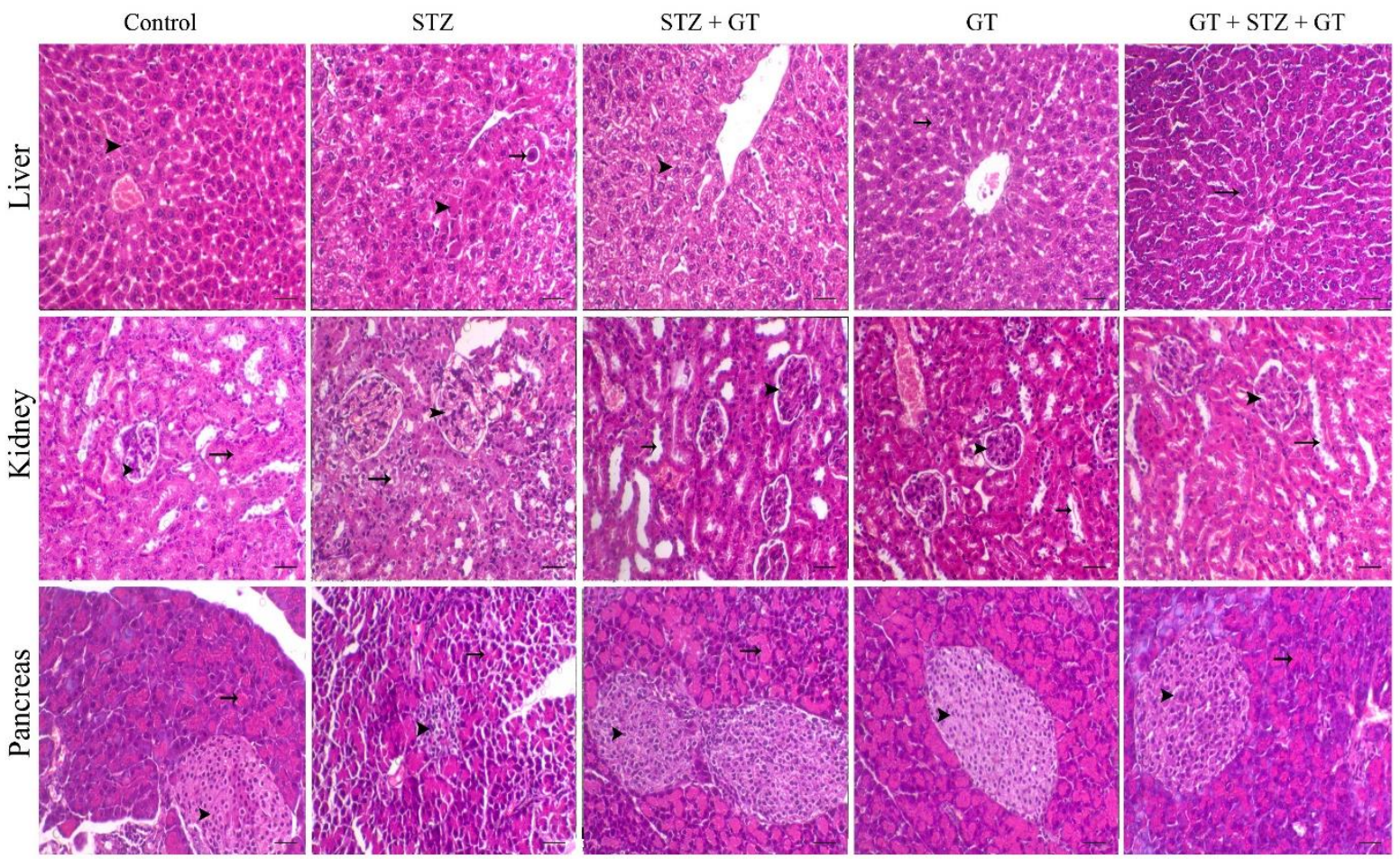

Figure 2: Histomicrograph of liver, kidney and pancreas of control group, STZ (diabetic) group, STZ+GT (green tea-treated STZ) group, GT (green tea) group and GT+STZ+GT (green tea-protective STZ) group. $\mathrm{H} \& \mathrm{E}, \mathrm{X} 200$ 

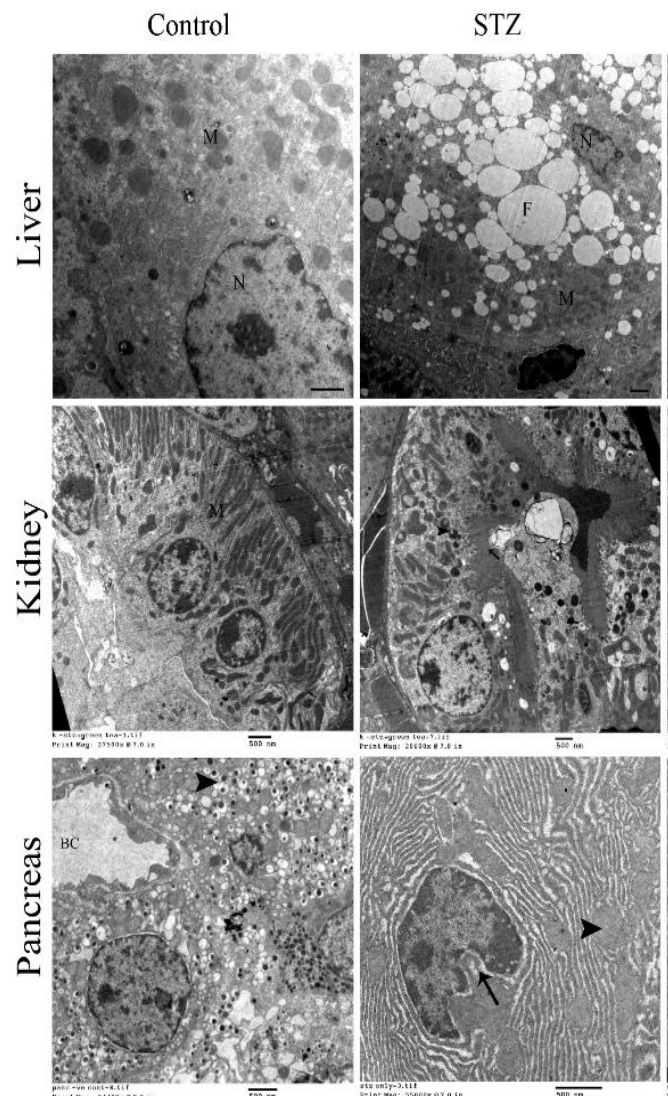

$\mathrm{STZ}+\mathrm{GT}$
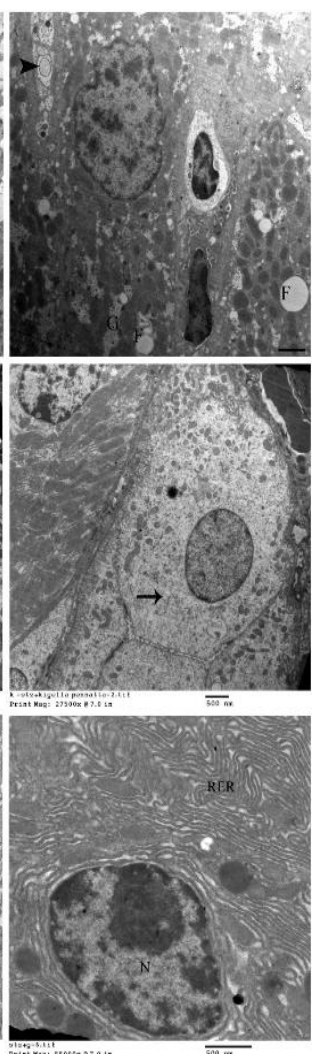

GT
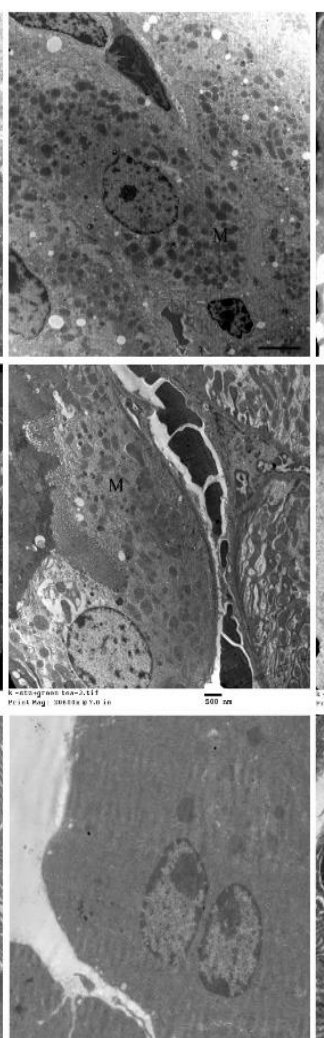

$\mathrm{GT}+\mathrm{STZ}+\mathrm{GT}$
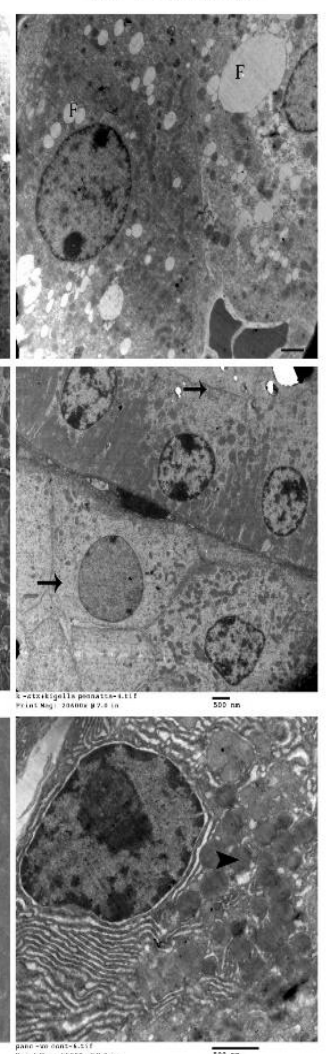

Figure 3: Electron micrograph of liver, kidney and pancreas of the control group, STZ (diabetic) group, STZ+GT (green tea-treated STZ) group, GT (green tea) group and GT+STZ+GT (green tea-protective STZ) group. Scale bar $=500 \mu \mathrm{m}$
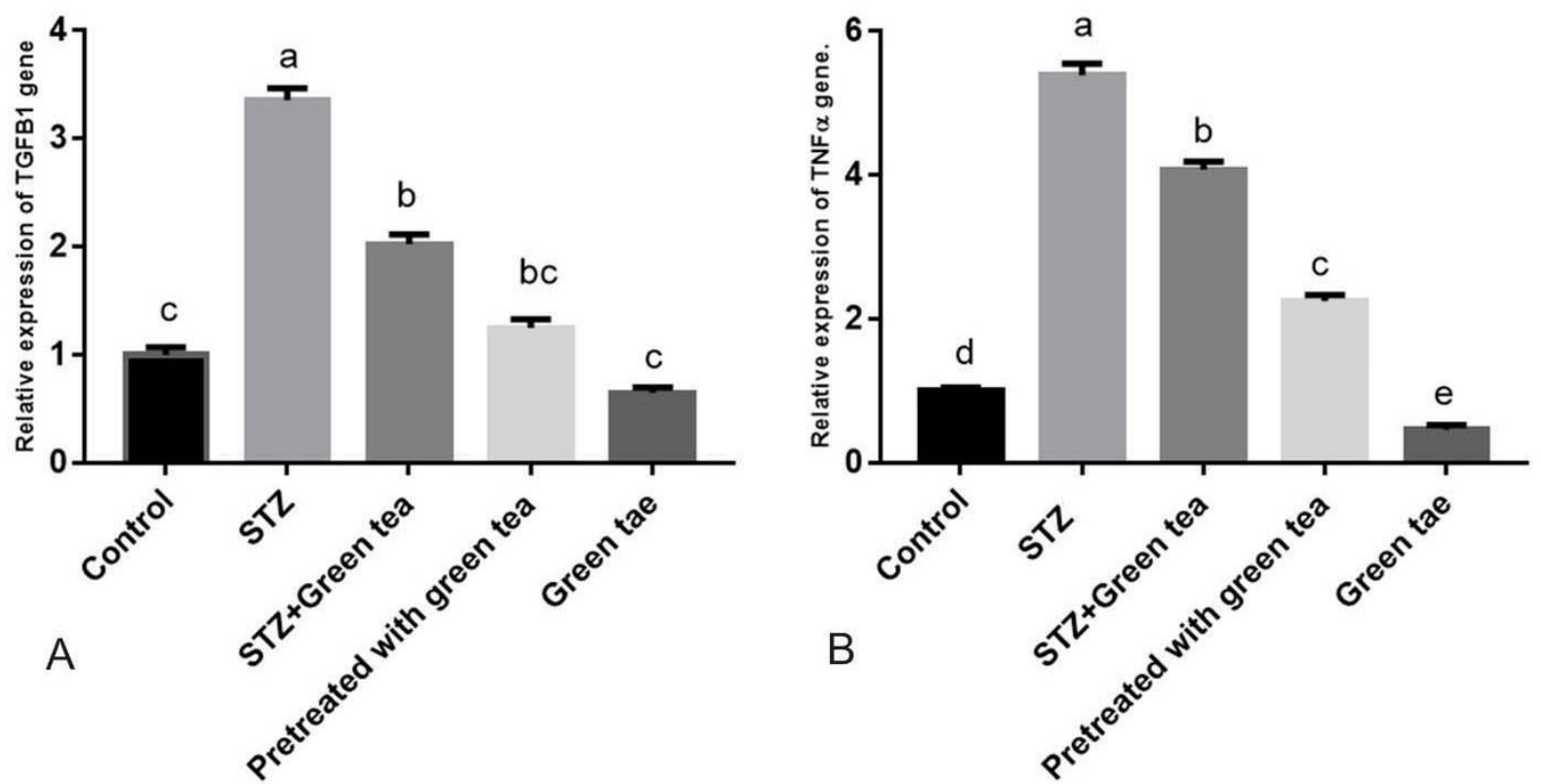

Figure 4: A. Effect of streptozotocin, green tea on the relative expression of $T G F \beta 1$ gene. Means within the same column carrying different superscript letters are significantly different $(\mathrm{P} \leq 0.05)$. B. Effect of Streptozotocin, green tea on the relative expression of TNF $\alpha$ gene. Means within the same column carrying -different superscript letters are significantly different $(\mathrm{P} \leq 0.05)$ 


\section{Discussion}

Diabetes is a metabolic ailment characterized by hyperglycemia. Its consequences from faults in insulin creation and this leads to disturbance in the metabolism followed by worsening of muscles which leads diabetic complications (36).

Our result revealed that diabetic mice had a significant drop in body weight as shown in figure 1. This result was consistent with (37-39) who reported momentous reduction in body weight in diabetic mice and attributed this effect to the highly muscle wasting and damage of tissue proteins.

Diabetic mice have a marked rise in the levels of serum glucose, triglycerides, cholesterol, LDL-C, VLDL-C when compared with control groups. The obtained data were parallel to that reported by (40) who found that diabetes induces substantial surges in the levels of these parameters and attributed this effect to insulin deficiency that hinder lipoprotein lipase triggering hypertriglyceridemia.

On the other hand, serum levels of insulin, total protein and HDL-C statistically decreased in STZ mice as compared to the control groups and these results agreed with (41-43) who reported similar reduction in these parameters in diabetic animals. Serum total protein in diabetic animals is obviously related to loss of structural proteins and drop in body weight which induced as a result of deficiency of insulin in diabetic mice.

Result revealed that, green tea extract in diabetic mice resulted in noteworthy regaining in body weight, decreases serum glucose in diabetic one, decrease cholesterol, triglyceride, and LDL-C levels, and improved serum total protein and HDL-C. In parallel, (44) also reported that administration of green tea extract in diabetic mice resulted in similar improvement and attributed them to the antihyperglycemic and hypolipidemic activity of green tea (45). Moreover, daily administration of green tea to diabetic mice decreased glucose levels and $\mathrm{HbA} 1 \mathrm{c}$ levels and this result was an in consistence with (47).
In the present study, diabetic mice showed a noteworthy rise in MDA relative to control animals. However, pre and post-treatment of diabetic animals with green tea lead to a marked decrease in MDA level. These results was compatible with that obtained by (46) who reported that increase in MDA can be the result of diabetic complications.

$\mathrm{MCV}, \mathrm{MCH}$, and MCHC markedly increased in diabetic mice as compared to control mice and suggesting occurrence of anemia in diabetic mice. This result agreed with (50) who reported that anemia in diabetes was due to the increased non-enzymatic glycosylation of RBC membrane proteins, which associated with hyperglycemic oxidation of this glycosylated membrane. In contrast, green tea normalized the elevated MCV, MCH, and MCHC of diabetic mice. These results were consistent with those obtained by (50) who attributed this effect to the decreased lipid peroxide in RBC membrane which decreases hemolysis. The disrupted body defense mechanism of the diabetic animal against infections was distressed due to the neutrophil role in diabetes (48). The obtained results were similar to those obtained by (49) who reported that diabetic mice had a decreased WBC count and attributed this to Streptozotocin ability to suppress the immune system through hindrance of leukocytosis in the bone marrow. We also found a decrease in platelets levels in diabetic mice. In parallel, (51) also reported that platelet accumulation ability in diabetic mice could be due to deficiency of insulin. In contrast, green tea can return this reduced level to a level comparable to that of the control animals. These results are consistent with (52) who reported this effect to green tea ability to increase the biosynthesis of clotting factors. Similar to results obtained by (53), we found no significant change in LH, FSH and estrogen levels among the groups.

Green tea treatment led to a significant down-regulation of $T G F \beta 1$ gene expression in liver. These results agreed with (54) who stated that green tea decreased hepatic expression of $T G F \beta 1$ and this accountable for reduction collagen synthesis and decrease fibrosis. Administration of green tea also led to significant 
downregulation of $T N F \alpha$ gene expression. In inconsistence, (55) established that green tea persuaded growth inhibition and apoptosis by decrease $T N F \alpha$ expression. TNF $\alpha$ expression may also have a valuable effect on diabetes since TNF $\alpha$ is intricate in developing diabetes.

Histopathological study and transmission electron microscope study revealed that administration of green tea can normalize the liver, kidney, pancreas and spleen that were deteriorated by STZ. In consistence, (56) reported that polyphenols (main ingredients in green tea) have anti-diabetic effects (57).

\section{Conclusion}

From the data found in this study, we can conclude that green tea has antidiabetic action though down-regulation of $T G F \beta 1$ and $T N F \alpha$ gene expression in liver, improvement of lipid metabolism and body weight in streptozotocin induced diabetic mice. This study verified the protective action of green tea on experimentally induced diabetic mice.

\section{Conflict of interest}

All authors declare that they have no conflict of interest.

\section{References}

1. Casqueiro J, Casqueiro J, Alves C. Infections in patients with diabetes mellitus: A review of pathogenesis. Indian journal of endocrinology and metabolism 2012; 16(Suppl1):S2-36.

2. Loghmani E. Diabetes mellitus: type 1 and type 2. Guidelines for adolescent nutrition services. 2005: 167-82.

3. Kangralkar V, Patil SD, Bandivadekar R. Oxidative stress and diabetes: a review. Int $\mathrm{J}$ Pharm Appl. 2010; 1 (1): 38-45.

4. Peleg AY, Weerarathna T, McCarthy JS, Davis TM. Common infections in diabetes: pathogenesis, management and relationship to glycaemic control. Diabetes/metabolism research and reviews 2007; 23 (1): 3-13.

5. Bukonla A, Benson OK, Akinsola AR, Aribigbola C, Adesola A, Seyi A. Effect of Type 1 Diabetes On Serum Electrolytes(Sodium and Potassium) Levels and Testosterone Hormone in Human Male Subjects. Webmed Central Biochemistry 2012; 3 (9): WMC003698.
6. Tesch GH, Allen TJ. Rodent models of streptozotocin-induced diabetic nephropathy (Methods in Renal Research). Nephrology. 2007; 12 (3): 2616.

7. Ventura-Sobrevilla J, Boone-Villa V, Aguilar C, Román-Ramos R, Vega-Avila E, CamposSepúlveda E, et al., editors. Effect of varying dose and administration of streptozotocin on blood sugar in male CD1 mice. Proc West Pharmacol Soc; 2011; $54: 5-9$

8. Eleazu C, Iroaganachi M, Eleazu K. Ameliorative potentials of cocoyam (Colocasia esculenta L.)and unripe plantain (Musa paradisiaca L.) on the relative tissue weights of streptozotocin-induced diabetic rats. Journal of diabetes research. 2013; 2013: $1-9$

9. RERUP CC. Drugs producing diabetes through damage of the insulin secreting cells. PharmacologicalReviews. 1970; 22 (4): 485-518.

10. Pham-Huy LA, He H, Pham-Huy C. Free radicals, antioxidants in disease and health. Int J Biomed Sci. 2008; 4 (2): 89-96.

11. Giugliano D, Ceriello A, Paolisso G. Oxidative stress and diabetic vascular complications. Diabetescare. 1996; 19 (3): 257-67.

12. Ceriello A. New insights on oxidative stress and diabetic complications may lead to a "causal" antioxidant therapy. Diabetes care. 2003; 26(5): 1589-96.

13. Cabrera C, Artacho R, Giménez R. Beneficial effects of green tea-a review. Journal of the American College of Nutrition. 2006; 25 (2): 79-99.

14. Nantz MP, Rowe CA, Bukowski JF, Percival SS. Standardized capsule of Camellia sinensis lowers cardiovascular risk factors in a randomized, double-blind, placebo-controlled study. Nutrition. 2009;2 5 (2): 147-54.

15. Iso H, Date C, Wakai K, Fukui M, Tamakoshi A. The relationship between green tea and total caffeine intake and risk for self-reported type 2 diabetes among Japanese adults. Annals of Internal Medicine. 2006; 144 (8): 554-62.

16. Wu CH, Lu FH, Chang CS, Chang TC, Wang RH, Chang CJ. Relationship among habitual tea consumption, percent body fat, and body fat distribution. Obesity research. 2003;11(9):1088-95.

17. Tsuneki H, Ishizuka M, Terasawa M, Wu JB, Sasaoka T, Kimura I. Effect of green tea on blood glucose levels and serum proteomic patterns in diabetic $(\mathrm{db} / \mathrm{db})$ mice and on glucose metabolism in healthy humans. BMC pharmacology. 2004;4 (1): 4-18.

18. Crespy V, Williamson G. A review of the health effects of green tea catechins inin vivo animal 
models. The Journal of nutrition. 2004; 134 (12): 3431S-40S.

19. Shinde UA, Sharma G, Xu YJ, Dhalla NS, Goyal RK. Insulin sensitising action of chromium picolinate in various experimental models of diabetes mellitus. Journal of Trace Elementsin Medicine and Biology. 2004; 1 8(1): 23-32.

20. Graham ML, Janecek JL, Kittredge JA, Hering BJ, Schuurman H-J. The streptozotocininduced diabetic nude mouse model: differences between animals from different sources. Comparative medicine. 2011; 61 (4): 356-60.

21. Abolfathi AA, Mohajeri D, Rezaie A, Nazeri M. Protective effects of green tea extract against hepatic tissue injury in streptozotocin-induced diabetic rats. Evidence-Based Complementary and Alternative Medicine. 2012; 2012: 740671-81.

22. Reeves PG, Nielsen FH ,Fahey Jr GC. AIN93 purified diets for laboratory rodents: final report of the American Institute of Nutrition ad hoc writing committee on the reformulation of the AIN-76A rodent diet. J nutr. 1993; 123 (11): 1939-51.

23. Maity S, Vedasiromoni JR, Ganguly DK. Role of glutathione in the antiulcer effect of hot water extract of black tea (Camellia sinensis). The Japanese Journal of Pharmacology. 1998; 78 (3): 285-92.

24. Yakubu M, Adesokan A, Akanji M. Biochemical changes in the liver, kidney and serum of rat following chronic administration of cimetidine. African Journal of Biomedical Research. 2006; 9(3): 213-8

25. Barham D, Trinder P. An improved colour reagent for the determination of blood glucose by the oxidase system. Analyst. 1972; 97 (1151):1425 .

26. Temple R ,Clark P, Hales C. Measurement of insulin secretion in type 2 diabetes: problems and pitfalls. Diabetic medicine. 1992; 9 (6): 503-12.

27. Ohkawa H, Ohishi N, Yagi K. Assay for lipid peroxides in animal tissues by thiobarbituric acid reaction. Analytical Biochemistry. 1979; 95 (2): $351-8$.

28. Arsie M, Marchioro L, Lapolla A, Giacchetto G, Bordin M, Rizzotti P, et al. Evaluation of diagnostic reliability of DCA 2000 for rapid and simple monitoring of HbAlc. Acta diabetologica. 2000; 37 (1): 1-7.

29. Guerci B, DurainD, Leblanc H, Rouland J, Passa P, Godeau T, et al. Multicentre evaluation of the DCA 2000 system for measuring glycated haemoglobin. DCA 2000 Study Group. Diabetes \& metabolism. 1997;23 (3): 195-201.
30. Allain CC, Poon LS, Chan CS, Richmond W, Fu PC. Enzymatic determination of total serum cholesterol. Clinical chemistry. 1974; 20 (4): 4705 .

31. Friedewald WT, Levy RI, Fredrickson DS. Estimation of the concentration of low-density lipoprotein cholesterol in plasma, without use of the preparative ultracentrifuge. Clinical Chemistry. 1972;18(6):499-502.

32. Darne F, McGarrigle H, Lachelin GC. Diurnal variation of plasma and saliva oestrogen, progesterone, cortisol and plasma dehydroepiandrosterone sulphate in late pregnancy. European Journal of Obstetrics \& Gynecology and Reproductive Biology. 1989; 32 (2): 57-66.

33. Dacie J, Lewis S. Practical Textbook of Haematology 7th Edition Edinburgh. Church Livingstone. 1991; 7:54-79.

34. Lillie RD. Histopathologic technic and practical histochemistry. Histopathologic technic andpractical histochemistry. 1954. 27(1): 73-6

35. Braet F, De Zanger R, Baekeland M, Crabbé E, Van Der Smissen P, Wisse E. Structure and dynamics of the fenestrae-associated cytoskeleton of rat liver sinusoidal endothelial cells. Hepatology. 1995; 21 (1): 180-9.

36. HallV, Thomsen RW, Henriksen O, Lohse N. Diabetes in Sub Saharan Africa 1999-2011: epidemiology and public health implications. A systematic review. BMC public health. 2011; 14 : 11-564.

37. Balamurugan R, Ignacimuthu S. Antidiabetic and hypolipidemic effect of methanol extract of Lippia nodiflora L. in streptozotocin induced diabetic rats. Asian Pacific Journal of Tropical Biomedicine. 2011; 1 (1): S30-S6.

38. Kumar R, Pate DK, Prasad SK, Sairam K, Hemalatha S. Antidiabetic activity of alcoholic leaves extract of Alangium lamarckii Thwaites on streptozotocin-nicotinamide induced type 2 diabetic rats. Asian Pacific journal of tropical medicine. 2011; 4 (11): 904-9.

39. Swanston-Flatt S, Day C, Bailey C, Flatt P. Traditional plant treatments for diabetes. Studies in normal and streptozotocin diabetic mice. Diabetologia. 1990;33(8):462-4.

40. Kasetti RB, Rajasekhar MD, Kondeti VK, Fatima SS, Kumar EGT, Swapna S, et al. Antihyperglycemic and antihyperlipidemic activities of methanol: water $(4: 1)$ fraction isolated from aqueous extract of Syzygium alternifolium seeds in streptozotocin induced diabetic rats. Food and Chemical Toxicology. 2010;48(4):1078-84. 
41. Surana S, Gokhale S, Jadhav R, Sawant R, Wadekar JB. Antihyperglycemic activity of various fractions of Cassia auriculata Linn. in alloxan diabetic rats. Indian journal of pharmaceutical sciences. 2008, 70 (2): 227-9

42. Yokozawa T, Yamabe N, Kim HY, Kang KS, Hur JM, Park CH, et al. Protective effects of morroniside isolated from Corni Fructus against renal damage in streptozotocin-induced diabetic rats. Biological and Pharmaceutical Bulletin. 2008; 31 (7): 1422-8.

43. Gupta R, Gupta RS. Effect of Pterocarpus marsupium in streptozotocin-induced hyperglycemic state in rats: comparison with glibenclamide. Diabetologia Croatica. 2009; 3 (2) : 945

44. Anandh Babu P, Sabitha K, Shyamaladevi C. GREEN TEA Extract Impedes Dyslipidaemia And Development Of Cardiac Dysfunction In Streptozotocin-Diabetic Rats. Clinical and Experimental Pharmacology and Physiology. 2006; 33 (12): 1184-9.

45. Kobayashi Y, Suzuki M, Satsu H, Arai S, Hara Y, Suzuki K, et al. Green tea polyphenols inhibit the sodium-dependent glucose transporter of intestinal epithelial cells by a competitive mechanism. Journal of Agricultural and Food Chemistry. 2000;48(11):5618-23.

46. Goycheva P, Gadjeva V, Popov B. Oxidative stress and its complications in diabetes mellitus. Trakia J Sci. 2006; 4 (1):1-8.

47. Fukino Y, Ikeda A, Maruyama K, Aoki N, Okubo T, Iso H. Randomized controlled trial for an effect of green tea-extract powder supplementation on glucose abnormalities. European journal of clinical nutrition. 2008;62(8):953-60.

48. Berkowitz DB, Kryspin-Sørensen I. Transgenic fish: Safe to eat? Nature Biotechnology. 1994; 12 (3): 247-52.

49. Oyedemi S, Yakubu M, Afolayan A. Effect of aqueous extract of Leonotis leonurus (L.) R. Br. leaves in male Wistar rats. Human \& experimental toxicology. 2010; 29 (5): 377-84.

50. Kennedy L, Baynes J. Non-enzymatic glycosylation and the chronic complications of diabetes: an overview. Diabetologia. 1984; 26 (2): 93-8

51. Jarald E, Joshi SB, Jain DC. Diabetes and herbal medicines. Iran J Pharmacol Ther. 2008; 7(1): 97-106.

52. Adebayo JO, Adesokan AA, Olatunji LA, Buoro DO, Soladoye AO. Effect of ethanolic extract of Bougainvillea spectabilis leaves on haematological and serum lipid variables in rats. 2005; 17 (1):-45-50.

53. Johnson LM, Sidman RL. A reproductive endocrine profile in the diabetes $(\mathrm{db})$ mutant mouse. Biology of reproduction. 1979; 20 (3): 552-9.

54. Abe K, Suzuki T, Ijiri M, Koyama Y, Isemura M, Kinae N. The anti-fibrotic effect of green tea with a high catechin content in the galactosamine-injured rat liver. Biomedical Research. 2007; 28 (1): 43-8.

55. Fujiki H, Suganuma M, Kurusu M, Okabe $S$, Imayoshi $\mathrm{Y}$, Taniguchi $\mathrm{S}$, et al. New TNF- $\alpha$ releasing inhibitors as cancer preventive agents from traditional herbal medicine and combination cancer prevention study with EGCG and sulindac or tamoxifen. Mutation Research/Fundamental and Molecular Mechanisms of Mutagenesis. 2003; 523: 119-25.

56. Li Y-W, Zhang Y, Zhang L, Li X, Yu J-B, Zhang H-T, et al. Protective effect of tea polyphenols on renal ischemia/reperfusion injury via suppressing the activation of TLR4/NF- $\mathrm{B}$ p65 signal pathway. Gene. 2014 ;542 (1): 46-51.

57. Yang Y-S, Wang C-J, Huang C-N, Chen ML, Chen M-J, Peng C-H. Polyphenols of Hibiscus sabdariffa improved diabetic nephropathy via attenuating renal epithelial mesenchymal transition. Journal of agricultural and food chemistry. 2013; 61(31): 7545-51. 